\title{
SECOND TRIMESTER ABORTION: MIFEPRISTONE PLUS MISOPROSTOL vs. MISOPROSTOL PLUS OXYTOCIN
}

\author{
AIDA PETCA ${ }^{1 \#}$, MONA ZVANCA $^{1 \#}$, MIHAELA BOT $^{1}$, RAZVAN-COSMIN PETCA $^{2 *}$, \\ CLAUDIA MEHEDINȚU ${ }^{3}$, SILVIUS NEGOIȚA ${ }^{4 \#}$, NICOLETA MARU ${ }^{5}$
}

${ }^{I}$ Department of Obstetrics and Gynaecology, Elias Emergency Hospital, "Carol Davila” University of Medicine and Pharmacy, Bucharest, Romania

${ }^{2}$ Department of Urology, "Prof. Dr. Th. Burghele" Clinical Hospital "Carol Davila” University of Medicine and Pharmacy, Bucharest, Romania

${ }^{3}$ Department of Obstetrics and Gynaecology, Malaxa Clinical Hospital, "Carol Davila" University of Medicine and Pharmacy, Bucharest, Romania

${ }^{4}$ Department of Anaesthesiology and Critical Care, Elias Emergency Hospital, "Carol Davila" University of Medicine and Pharmacy, Bucharest, Romania

${ }^{5}$ Department of Anatomy, "Carol Davila” University of Medicine and Pharmacy, Bucharest, Romania

*corresponding author: drpetca@gmail.com

${ }^{\#}$ Authors with equal contribution

Manuscript received: February 2019

\begin{abstract}
The study compares outcomes from simultaneous administration of Mifepristone and Misoprostol (M\&M) with a regimen in which Misoprostol is associated with Oxytocin (M\&O) for second-trimester abortion. The primary outcome was uterine evacuation within 12 hours after the first Misoprostol dose, secondary outcomes were adverse effects, post-abortion complications and average cost per patient for each method. 108 patients were enrolled with equal distribution and abortion was complete in both groups. In the M\&M group the induction-abortion interval (I-AI) was less than 12 hours in $62.96 \%(\mathrm{n}=34)$ compared with the M\&O group with $22.22 \%(n=12), p<0.05$. Both regimens had high acceptability rates. We did not find any statistical difference in adverse effects observed between the two groups. Administering M\&M simultaneously resulted in grater expulsion rates within 12 hours compared with $\mathrm{M} \& \mathrm{O}$, with the latter regimen demonstrating synergistic benefits, with lower expenses and satisfactory I-AI.
\end{abstract}

\section{Rezumat}

Scopul studiului a fost compararea rezultatelor obținute după administrarea simultană de Mifepristonă și Misoprostol (M\&M) într-o abordare terapeutică în care Misoprostol este asociat cu Oxitocină (M\&O) pentru inducerea avortului în trimestrul al doilea. Rezultatul principal urmărit a fost evacuarea uterină în 12 ore după prima doză de Misoprostol, în al doilea rând s-au urmărit efectele adverse, complicațiile post-avort și costul mediu per pacient pentru fiecare metodă. 108 paciente au fost înrolate și distribuite uniform; avortul a fost complet în ambele grupuri. În grupul M\&M intervalul inducție-avort (I-IA) a fost mai mic de 12 ore în procent de 62,96\% ( $n=34)$ comparat cu grupul M\&O cu 22,22\% $(n=12), p<0,05$. Ambele scheme farmaclogice au avut rate ridicate de complianță. $\mathrm{Nu}$ am obținut diferențe semnificative statistic între cele două grupuri în ceea ce privește efectele adverse. Administrarea simultană de $M \& M$ a condus la rate mai mari de avort în 12 ore comparativ cu $\mathrm{M} \& \mathrm{O}$. Utilizarea concomitentă a $\mathrm{M} \& \mathrm{O}$ a demonstrat efecte sinergice benefice, cu cheltuieli mai mici și I-IA satisfăcătoare.

Keywords: Misoprostol, Mifepristone, Oxytocin, medical abortion, simultaneous administration, sublingual/vaginal

\section{Introduction}

Lately, the increasing number of specialists in the field of Maternal-Foetal Medicine improved the management of high risk pregnancies [34] and permitted the early-first trimester diagnosis [35] of foetal anomalies, thus the vast majority of abortions are performed in the first trimester. The delayed diagnosis of foetal anomalies, logistic and financial difficulties in completing the invasive investigations in the first trimester still maintain the need for second trimester abortion. Although second trimester abortions constitute only 10 to $15 \%$ of all induced abortions worldwide, they are responsible for almost two-thirds of all major abortion-related complications. The means to terminate a second trimester pregnancy are either medical or surgical; the surgical approach dilatation and evacuation, needs complicated procedures. The complications of the surgical approach like perforation, haemorrhage, cervical lacerations, infection, major unintended surgery and sterility make the medical methods for induced abortion preferable because of the lower maternal mortality and morbidity rates associated. Also obtaining the foetus intact allows for confirmation of the congenital anomaly through dissection and provides valuable information 
FARMACIA, 2019, Vol. 67, 5

for future pregnancies. Since 2000, Misoprostol, a synthetic prostaglandin E1 analogue, has been widely used for medical abortion, inducing cervical effacement and uterine contractions [29]. The efficiency of misoprostol alone is up to $80-90 \%$ of the cases. A combination of misoprostol and mifepristone, an orally active antiprogesterone [15], has been approved and is successfully used for first trimester abortion and might share the same success in the second trimester. Traditionally, misoprostol's effect was augmented with oxytocin, in different doses. The combination of Mifepristone and Misoprostol is only approved for early first trimester termination in Romania and we dared to conduct the study using this design once more studies showed that the combined regimen is most effective and fastest for second trimester abortion $[5,11]$.

The aim of our study was to compare the efficacy and safety of combining Mifepristone at the same time with Misoprostol versus Oxytocin after Misoprostol use in second trimester in order to considerably reduce the induction-abortion interval (I-AI), while taking into consideration the possible adverse reaction and the costs of both regimens.

Misoprostol is a synthetic, water soluble, 15-deoxy-16hydroxy-16-methyl analogue of PGE1. The commercial preparation available in Romania is Misoprostol $0.2 \mathrm{~g}$, drom of Medabon (Sun Pharmaceutical Industries Europe BV) and Topogyne $0.4 \mathrm{~g}$ (Exelgyn) since 2012, 2013 respectively. Misoprostol is not expensive, stable at room temperature and can be stored for a long time. Since 2014 Misoprostol is available also as vaginal delivery system, containing $200 \mu \mathrm{g}$, Misodel ${ }^{\mathbb{R}}$ (Ferring Pharmaceuticals Ltd), which must be stored in a freezer $\left(-10\right.$ to $\left.-25^{\circ} \mathrm{C}\right)$.

Misoprostol is rapidly absorbed following oral administration with peak plasma concentrations of the active metabolite (misoprostolic acid) after about 15 minutes. Time of half-life for the misoprostolic acid is between 20 and 40 minutes. Misoprostol is mainly metabolized by the oxidation systems of fatty acids in the liver, and less than $1 \%$ excreted in the urine. There are no known drug interactions of misoprostol. The route of administration of misoprostol is equally important, as at the beginning, misoprostol was only used as an oral tablet. The vaginal route appears to be the most effective, followed by sublingual and oral route being the least effective [2]. Mifepristone, also known as 11 $\beta$-(4-(dimethylamino)phenyl)-17 $\alpha$-(1-propynyl) estra-4,9-dien-17 $\beta$-ol-3one, is a synthetic 19-norsteroid which binds with high affinity to the progesterone receptor, thus inhibiting the effect of the hormone. The commercial preparation available in Romania is Mifepriston 0.2 mg, from Medabon (Sun Pharmaceutical Industries Europe BV) and Mifegyne $0.2 \mathrm{~g}$ (Exelgyn) since 2012, 2013 respectively. Mifepriston is affordable, stable at room temperature and can be stored for a long time. Until now it is the only anti-progestin approved for the induction of abortion.

Following oral administration, mifepristone is rapidly absorbed with a peak plasma concentration of 1.98 $\mathrm{mg} / \mathrm{L}$ reached after 1.30 hours. The medium time for half-life is approx. 18 hours, but the elimination is complex [18]. Metapristone is the major metabolite of mifepristone. Mifepristone is metabolized by the hepatic oxidative metabolism through the $\mathrm{N}$ demethylation and terminal hydroxylation of the 17propynyl chain pathways and is excreted primarily by faeces.

Oxytocin is normally a peptide hormone, produced by the paraventricular nucleus of the hypothalamus and released by the posterior pituitary in the bloodstream [24]. The hormone is prepared synthetically to avoid possible contamination with vasopressin $(\mathrm{ADH})$ and other small polypeptides with biologic activity. The commercial preparation available in Romania is Oxytocin (Ferring-Leciva) vials of 2 or 5 UI. Oxytocin is inexpensive, must be stored at 2 $8^{\circ} \mathrm{C}$ and can be administered only by IV or IM route. Oxytocin effect is immediate after IV administration and subsides after 1 hour, after IM administration occurs in 3 - 5 min and decreases within 2 - 3 hours. The half-life for the oxytocin is $1-6 \mathrm{~min}$ and decreases in late pregnancy and during lactation. Oxytocin determines uterine contractions by increasing the intracellular $\mathrm{Ca}^{2+}$, which in turn activates myosin's light chain kinase. The hormone has specific receptors in the muscle lining of the uterine wall and their concentration increases greatly as the pregnancy advances, reaching a maximum level in early labour at term. Oxytocin is rapidly metabolized in the liver and in the plasma by oxytocinases. Oxytocin in high doses (over 40 milliunits/min) for a long time can produce severe water intoxication due to its antidiuretic effect [32].

\section{Materials and Methods}

Study design

The present study was conducted in the Department of Obstetrics and Gynaecology, Elias Universitary Emergency Hospital, Bucharest, Romania from December 2014 to September 2018. The study design and written consent was approved by the Ethical Committee of Elias Universitary Emergency Hospital. A total of 108 patients were selected with gestational ages between 16 to 24 weeks with various indications for termination of pregnancy. There were equal number of nulliparous women - 17 and multiparous women - 37 in both groups. The medical profiles of all patients who were admitted for medical termination of a second-trimester pregnancy were reviewed. We didn't consider previous caesarean delivery as a contraindication for medical termination. The subjects were divided into two groups, equally distributed: 
Group 1: Women who received Mifepristone and Misoprostol simultaneously and Group 2: Women who received Misoprostol followed by Oxytocin.

Inclusion Criteria: gestational age between 16 to 24 weeks; singleton pregnancy; no regular uterine contractions.

Exclusion Criteria: grand multipara ( $>4)$; multiple pregnancy; known cases of heart problems, renal, liver or respiratory disease, hypersensitivity to Mifepristone, Misoprostol or Oxytocin, current long-term systemic corticosteroid therapy - because of the interference with the Mifepristone's effect, chronic adrenal failure, inherited porphyria, haemorrhagic (coagulation) disorder or severe anaemia.

The procedure was explained to all eligible patients and their written informed consent was taken. Women in the first group were given Mifepristone (200 mg) orally and Misoprostol (400 $\mu \mathrm{g}$ ) vaginally followed by Misoprostol sublingual $(50 \mathrm{mcg}$ ) and vaginally $(50 \mathrm{mcg}$ ) after $6 \mathrm{hrs}$ which may be repeated every 6 hrs, to a maximum of 5 doses. Women in the second group were given half tablet Misoprostol $(200 \mu \mathrm{g})$ vaginally followed by Misoprostol sublingual (50 $\mu \mathrm{g})$ and vaginally $(50 \mu \mathrm{g})$ after $6 \mathrm{hrs}$ which may be repeated every $6 \mathrm{hrs}$, to a maximum of 5 doses and we associated 10 UI Oxytocin IV in $500 \mathrm{~mL}$ saline solution when contractions initiated.

Patients were monitored regarding the onset of contractions, presence of bleeding, side-effects like fever, shivering, nausea, vomiting, headache, diarrhoea, hypertonicity and completion of abortion. Intravenous antibiotics were administered after admission to all patients when vaginal misoprostol was placed. Once the contractions were installed and became painful, all patients had epidural catheter placed thus the pain wasn't a problem in our study groups.
The standard protocol included check curettage post abortively in both groups. Anti-D immunoglobulin $(150 \mu \mathrm{g})$ was administered to all patients with negative blood type within $72 \mathrm{~h}$ after contractions initiated.

Once the pregnancy was terminated, the following complications were noted: severe haemorrhage requiring blood transfusion, uterine infection with the clinical picture consisting with endometritis, retained placenta and uterine rupture. Every patient received ablactation drugs post abortive - Cabergoline $0.5 \mathrm{mg}$ (Dostinex ${ }^{\circledR}$ ), 2 tablets orally, once.

Statistical analysis

Statistical analysis was conducted with Statistical Package for the Social Sciences (SPSS) 22 version for Windows (IBM, Armonk, NY, USA). Qualitative data have been analysed as frequency and percentage [6]. Results were considered statistically significant at $\mathrm{p}<$ 0.05, using Chi-Square test.

\section{Results and Discussion}

In Group 1 the maximum dose of misoprostol required was $1000 \mu \mathrm{g}$, while in Group 2 - 15 patients required $700 \mu \mathrm{g}$ and 2 patients required $900 \mu \mathrm{g}$. In Group 2 the maximum dose of oxytocin was 30 units (6 cases, all nulliparous). Abortion was complete in both groups. In the $\mathrm{M} \& \mathrm{M}$ group induction abortion interval was less than 12 hours in $62.96 \%(\mathrm{n}=34)$ cases, compared to $22.22 \%(\mathrm{n}=12)$ in the $\mathrm{M} \& \mathrm{O}$ group, $\mathrm{p}=0.025$ (Table I and Figure 1); the I-AI between 12 to 18 hours was found in $35.18 \%$ ( $\mathrm{n}=$ 19) cases in group 1 compared $62.96 \%(n=34)$ in group 2. The characteristics of women from both groups, as well as the indications for pregnancy termination, are presented in Table II.

Table I

Induction-Abortion Interval (I-AI)

\begin{tabular}{|c|c|c|c|c|}
\hline Duration & \multicolumn{2}{|c|}{ Group 1 } & \multicolumn{2}{c|}{ Group 2 } \\
\hline & Nulliparous & Multiparous & Nulliparous & Multiparous \\
\hline$<6$ hours & 2 & 6 & 0 & 3 \\
\hline $6-12$ hours & 6 & 20 & 2 & 7 \\
\hline $12-18$ hours & 8 & 11 & 9 & 25 \\
\hline $18-24$ hours & 1 & 0 & 6 & 2 \\
\hline
\end{tabular}

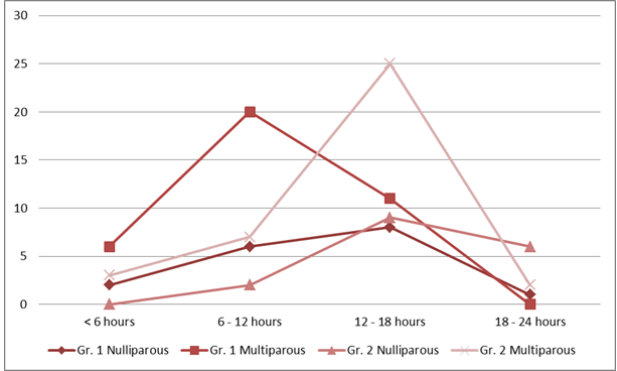

Figure 1.

Cumulative abortion rate
Table II

Patient's characteristics in both groups

\begin{tabular}{|c|c|c|}
\hline Variable & Group 1 & Group 2 \\
\hline Maternal age (years) & $29(21-38)$ & $30(22-39)$ \\
\hline Gestational age (weeks) & $21(16-24)$ & $20(16-24)$ \\
\hline Previous caesarean section & 7 & 5 \\
\hline \multicolumn{2}{|c|}{ Indication for termination } \\
\hline Foetal abnormalities & 12 & 16 \\
\hline Chromosomal defects & 20 & 17 \\
\hline Congenital infections & 3 & 1 \\
\hline Hydrops fetalis & 1 & 0 \\
\hline Foetal death & 16 & 17 \\
\hline Maternal disease & 2 & 3 \\
\hline
\end{tabular}

Values are presented as $\mathrm{n}$ or median (range) 
FARMACIA, 2019, Vol. 67, 5

We did not find any statistical difference in adverse effects observed between the two groups (Table III).

\section{Table III}

Adverse effects

\begin{tabular}{|c|c|c|c|c|c|}
\hline Adverse effect & \multicolumn{2}{|c|}{ Group 1} & \multicolumn{2}{|c|}{ Group 2} & 1 \\
\hline & No. & $\%$ & No. & $\%$ & $\mathrm{p}$ value \\
\hline fever & 1 & 1.85 & 1 & 1.85 & 0.363 \\
\hline shivering & 0 & & 1 & 1.85 & - \\
\hline nausea & 2 & 3.7 & 2 & 3.7 & 0.672 \\
\hline vomiting & 1 & 1.85 & 1 & 1.85 & 0.363 \\
\hline headache & 0 & & 1 & 1.85 & - \\
\hline diarrhoea & 2 & 3.7 & 0 & & - \\
\hline hypertonicity & 0 & & 1 & 1.85 & - \\
\hline
\end{tabular}

Twelve women had prior caesarean delivery and the method of induction was no different to the others. 3 out of 7 in Group 1 received $500 \mu \mathrm{g}$ of Misoprostol, while the other 4 out of 7 needed $700 \mu \mathrm{g}$ to terminate the pregnancy. In Group 2, 2/5 received $400 \mathrm{mcg}$ Misoprostol and 10 units Oxytocin and $3 / 5$ needed $600 \mathrm{mcg}$ Misoprostol and 15 units of Oxytocin. The delivery in all cases was successfully without any adverse events.

Complications occurred in 5.55\% $(\mathrm{n}=3)$ cases in Group 1 compared to $12.96 \%(n=7)$ in Group 2 . Vaginal expulsion of the foetus was obtained in all cases. We encountered severe haemorrhage during delivery of the placenta in 5 cases, 2 in Group 1 and 3 in Group 2 (3.7\% compared to $5.55 \%$ ); all women received a single unit transfusion of red blood cells. The retained placenta was removed surgically, with grasp forceps before check curettage in 2 cases from Group 2. The complications in both groups are presented in Table IV.

Table IV

Complications following termination of pregnancy

\begin{tabular}{|c|c|c|}
\hline Complications & Group 1 & Group 2 \\
\hline severe haemorrhage & 2 & 3 \\
\hline uterine infection & 1 & 2 \\
\hline retained placenta & 0 & 2 \\
\hline uterine rupture & 0 & 0 \\
\hline
\end{tabular}

Since ancient times, various surgical and medical methods of abortion have been used. Surgical abortion dilation and evacuation (D\&E), is one of the oldest, fastest and most commonly practised techniques in many parts of the world [8], but it needs experienced hands and carries the disadvantage of compromising the foetus, which is frequently used for the confirmation of the congenital anomaly through dissection and provides valuable information for future pregnancies. Taking these to consideration, medical methods are preferred by specialist practitioners.

Misoprostol is long known as a potent uterotonic agent, highly efficacious for labour induction. A low-dose misoprostol regimen for second trimester pregnancy termination was first described by Jain $e t$ al. in 1994 [14]. Since then, different investigations have suggested that higher efficacity is easily obtained with increasing doses of misoprostol [9, 14, 31]. The association of misoprostol with concentrated oxytocin was explored for second trimester pregnancy interruption with minimal side-effects profile and low live birth rate [20]. Medical abortion for first trimester pregnancies was further improved when mifepristone became available in the 1980s [27, 30]. The method was then explored and proposed for second trimester abortions [10]. The association between mifepristone and misoprostol shortened the I-AI and decreased the dose of prostaglandin analogues required, significantly reducing the side effects.

ACOG Practice Bulletin published in 2013 and reaffirmed in 2017 states that the regimens for second trimester medical abortion should comprise: as the first line Mifepristone, $200 \mathrm{mg}$, administered orally, followed in 24 - 48 hours by Misoprostol vaginally $800 \mu \mathrm{g}$, followed by $400 \mu \mathrm{g}$ administered vaginally, sublingually or orally every 3 hours, maximum 2000 $\mu \mathrm{g}$; whenever Mifepristone is not available, the method of choice would be Misoprostol, $400 \mu \mathrm{g}$, vaginally or sublingually every 3 hour to a maximum of $2000 \mu \mathrm{g}$ and last, when Misoprostol is not available, Oxytocin, 20 - 100 units, infused IV over 3 hours period, followed by a pause of 1 hour to allow diuresis, increased to a maximum of 300 units over 3 hours [21]. Although there are studies which stipulate the necessity for a 24 hours' time lapse for the efficacy of Mifepristone to be evident we decided to administer Mifepristone in the same time with Misoprostol in the M\&M group to aim for an outcome of shorter hospitalization time $[3,23,28]$. The results were encouraging: 53 of $54(98.14 \%)$ of women aborted in less than 18 hours, which allowed us to obtain a maximum 36 hours hospital stay for almost 95\% $(n=$ 51) of the patients, with 2 cases needing an extra day of hospitalization, blood transfusion in one case and administration of IV antibiotics in another. The study demonstrated that eliminating the interval recommended by most of the studies between the mifepristone and misoprostol has the potential to reduce hospital stay, inherent extra time and other costs to receive a tablet of mifepristone in order to obtain approximately the same benefits, as Abbas et al. concluded also [1]. However, recent studies and decades of research have established that mifepristone is a safe drug, thus it might be administered at home without medical supervision in order to reduce the time period to be spent in the hospitals [25].

As part of the second outcomes we evaluated the synergy between Misoprostol and Oxytocin in Group 2, in order to reduce the need of higher doses of prostaglandins, which are known to be associated with gastro-intestinal side effects [29]. This regimen is long known $[22,33]$ as satisfactory efficient for second trimester termination of pregnancy and allowed us to report a good I-AI, as $85.18 \%(n=46)$ of 
FARMACIA, 2019, Vol. 67, 5

patients delivered in less than 18 hours, after a maximum dose of $900 \mu \mathrm{g}$ of Misoprostol. The complications rates were similar between the two groups.

Gestational age and parity did not significantly influence I-AI. However, women at 18 - 24 weeks of gestation received more misoprostol doses and experienced a longer time to completion, due to larger foetal size requiring more cervical dilation, confirming findings from other studies $[11,29]$.

In balancing the use of both regimens for the termination of second trimester pregnancy, we calculated the costs/benefits of the specific medication for each group. The advantages of Mifepristone and Misoprostol are given by the high stability at room temperature and that both can be stored for a long time, as Oxytocin must be refrigerated and must be infused IV for a proper effect; but, the medium cost per patient was five-fold greater in Group 1 compared to Group 2. Mifepristone, as we have mentioned above, is listed only for first trimester abortions, and because it is not available in hospitals, the patient has to pay separately for the medication. Misoprostol is cheaper, but also not available in hospitals. The only Misoprostol available in hospitals is Misodel ${ }^{\circledR}$, $200 \mu \mathrm{g}$, an insufficient dose for second trimester abortions and an expensive product. The second regimen is consistently cheaper and satisfactory efficient whenever mifepristone is unavailable or unaffordable, although the efficacy is lower than the combined regimen Mifepristone/Misoprostol, same as other studies concluded $[5,11]$.

All women develop abdominal cramps due to uterine contractions, which are needed to abort the pregnancy. Many studies reported that appropriate information and pain medication allow the woman to relax, which reduces discomfort $[11,23,24]$, recommending that future studies should focus on improving pain management [11]. In our study, all women in both groups benefited of epidural analgesia from the moment when painful contractions initiated, which is known as extremely effective and popular for labour pain [26], thus other pain relief medications were not necessary. We report shorter I-AI in both study groups and that fact might be explained by the better progression of cervical dilation in the presence of epidural analgesia, as other authors report, but referring only to labour $[12,13,17]$.

The most serious complication using misoprostol in pregnancy terminations with a previous uterine scar is the risk of uterine rupture [16]. In our study 7 patients in Group 1 and 5 patients in Group 2 (12.95\% compared to $9.25 \%$ ) had a scarred uterus. Considering the small amounts of Misoprostol administered in both groups we didn't adjust the doses by half as other studies suggested [4, 19], but the limitation of our study is that patients with previous $\mathrm{C} / \mathrm{S}$ are not enough to make a conclusion for the rate of complications. Even so, we might explain our success as a consequence of the lower gestational age (until 24 weeks, which is the upper limit of pregnancy termination for medical reasons in Romania) of our cases.

Until now, several studies have been conducted to investigate the optimal route and dosage of misoprostol administration $[11,23,28]$ and, unfortunately, resulted in a wide variation in reported outcomes and the regimen of misoprostol adopted, so no consensus has been reached.

The main difference between our two protocols and other studies is the combined route of administration and dosage of Misoprostol. To our knowledge, this is the only study conducted with this design. In our decision to consider this study design we balanced two known facts: the sublingual route allows rapid absorption and has higher bioavailability, while the vaginal route has fewer side effects and produces more prolonged uterine contractions, thus requiring smaller doses. FIGO guideline suggests the use of either routes. There are a lot of studies comparing the results of sublingual and vaginal routes, but this is the first with combining regimen [7, 11, 29]. The reported side effects of misoprostol are primarily gastrointestinal, distributed approximately even in both groups as adverse effects are often associated with sublingual route of administration, so nausea, vomiting and diarrhoea appeared in 5 cases in Group 1 and 3 patients in Group 2. The side effects were similar to those reported by previous studies and proportional with the dose of Misoprostol ingested $[3,10,11,22]$.

Our study confirms the superiority of Mifepristone/ Misoprostol regimen, as measured by significant shortening of the induction-to-abortion interval and increased rate of induction success at 12 hours, for second trimester pregnancy termination. The concurrent use of Misoprostol with concentrated oxytocin demonstrated synergistic benefits, with lower expenses and satisfactory induction-to-abortion intervals (under 18 hours), better results than those reported by Nuthalapaty et al. [20].

\section{Conclusions}

Our findings show that administering Mifepristone and Misoprostol sublingually and vaginally as a simultaneous regimen results in good clinical outcomes, providing a good I-AI and a great abortion rate. But, whenever the cost is an issue to be considered by the practitioner, Misoprostol sublingually and vaginally associated with concentrated Oxytocin is a satisfactory alternative regimen. Our I-AI could be explained by the positive effect on cervical dilation of epidural analgesia.

Further studies are needed, on a larger scale, to evaluate if this is the optimal combination of 
Mifepristone and Misoprostol in women with prior caesarean section. For sure, medical termination of pregnancy is safer and provides a good histological specimen in cases of foetal malformation and represents the response to the need to further reduce unnecessary surgical evacuation of second trimester pregnancies.

\section{Conflict of interest}

The authors declare that they have no potential conflicts of interest to disclose.

\section{References}

1. Abbas DF, Blum J, Ngoc NT, Nga NT, Chi HT, Martin R, Winkoff B, Simultaneous administration compared with a 24-hour mifepristone-misoprostol interval in second-trimester abortion. Obstet Gynecol., 2016; 128(5): 1077-1083.

2. Allen R, O'Brien BM, Uses of misoprostol in obstetrics and gynecology. Rev Obstet Gynecol., 2009; 2(3): 159-168.

3. Ashok PW, Templeton A, Nonsurgical mid trimester termination of pregnancy: a review of 500 consecutive cases. Br J Obstet Gynecol., 1999; 106(7): 706-710.

4. Berghella V, Airoldi J, O’Neill A, Einhorn K, Hoffman $\mathrm{M}$, Misoprostol for second trimester pregnancy termination in women with prior caesarean: a systematic review. Br J Obstet Gynecol., 2009; 116(9): 1151-1157.

5. Borgatta L, Kapp N, Clinical guidelines. Labor induction abortion in the second trimester. Society of Family Planning. Contraception, 2011; 84(1): 4-18.

6. Braticevici B, Petca R, Petrescu A, Jinga V, Ionita $\mathrm{L}$, Incidentally detected prostate cancer in patients undergoing radical cystoprostatectomy. Rom Biotechnol Lett., 2014; 19(1): 9051-9057.

7. Cetin C, Buyukkurt S, Seydaoglu G, Kahveci B, Soysal C, Ozgunen FT, Comparison of two misoprostol regimens for mid-trimester pregnancy terminations after FIGO's misoprostol dosage recommendation in 2012. J Matern Fetal Neonatal Med., 2016; 29(8): 1314-1317.

8. Chasen ST, Kalish RB, Gupta M, Kaufman JE, Rashbaum WK, Chervenak FA, Dilation and evacuation at $\geq$ 20 weeks: comparison of operative techniques. $\mathrm{Am}$ J Obstet Gynecol., 2004; 190(5): 1180-1183.

9. Dickinson JE, Evans SF, The optimization of intravaginal misoprostol dosing schedules in secondtrimester pregnancy termination. Am J Obstet Gynecol., 2002; 186(3): 470-474.

10. El-Refaey H, Templeton A, Pregnancy: Induction of abortion in the second trimester by a combination of misoprostol and mifepristone: a randomized comparison between two misoprostol regimens. Human Reprod., 1995; 10(2): 475-478.

11. Gemzell-Danielsson K, Lalitkumar S, Second trimester medical abortion with mifepristone-misoprostol and misoprostol alone: a review of methods and management. Reprod Health Matters., 2008; 16(supp31): 162-172.

12. Genc M, Sahin N, Maral J, Celik E, Kar AA, Usar P, Korkut B, Guclu S, Does bupivacaine and fentanyl combination for epidural analgesia shorten the duration of labour?. J Obstet Gynaecol., 2015; 35(7): 672-675.

13. Gomar C, Fernandez C, Epidural analgesia-anaesthesia in obstetrics. Eur J Anaesthesiol., 2000; 17(9): 542-558.

14. Jain JK, Mishell Jr DR, A comparison of intravaginal misoprostol with prostaglandin $\mathrm{E} 2$ for termination of second-trimester pregnancy. N Engl J Med., 1994; 331(5): 290-293.

15. Johannisson E, Oberholzer M, Swahn ML, Bygdeman $\mathrm{M}$, Vascular changes in the human endometrium following the administration of the progesterone antagonist RU 486. Contraception, 1989; 39(1): 103-117.

16. Küçükgöz Güleç Ü, Urunsak IF, Eser E, Guzel AB, Ozgunen FT, Evruke IC, Buyukkurt S, Misoprostol for midtrimester termination of pregnancy in women with 1 or more prior cesarean deliveries. Int J Gynecol Obstet., 2013; 120(1): 85-87.

17. Lurie S, Matzkel A, Epidural anesthesia shortens duration of labor in singleton vertex presentation spontaneous delivery. Asia Oceania J Obstet Gynaecol., 1991; 17(3): 203-205.

18. Mahajan DK, London SN, Mifepristone (RU 486): a review. Fertility and Sterility, 1997; 68(6): 967-976.

19. Naguib AH, Morsi HM, Borg TF, Fayed ST, Hemeda $\mathrm{HM}$, Vaginal misoprostol for second trimester pregnancy termination after one previous cesarean delivery. Int J Gynecol Obstet., 2010; 108(1): 48-51.

20. Nuthalapaty FS, Ramsey PS, Biggio JR, Owen J, High-dose vaginal misoprostol versus concentrated oxytocin plus low-dose vaginal misoprostol for midtrimester labor induction: a randomized trial. Am J Obstet Gynecol., 2005; 193(3): 1065-1070.

21. Obstetricians ACo, Gynecologists. ACOG practice bulletin No. 135: second-trimester abortion. Obstet Gynecol., 2013; 121(6): 1394-1406.

22. Owen J, Hauth JC, Concentrated oxytocin plus lowdose prostaglandin E2 compared with prostaglandin E2 vaginal suppositories for second-trimester pregnancy termination. Obstet Gynecol., 1996; 88(1): 110-113.

23. Patel U, Chauhan K, Singhi S, Kanani M, Second trimester abortion-mifepristone and misoprostol or misoprostol alone. Int J Reprod Contracept Obstet Gynecol., 2013; 2(3): 315-319.

24. Pădurariu M, Balmuș M, Ciobîcă A, Lefter R, Cojocaru S, Antioch I, Foyet H, Dobrin R, Ababei DC, Bild V, Oxytocin administration improves memory, anxiety and some oxidative stress parameters in a methionine induced rat model of schizophrenia. Farmacia, 2017; 66(3): 421-431.

25. Raymond EG, Grossman D, Wiebe E, Winikoff B, Reaching women where they are: eliminating the initial in-person medical abortion visit. Contraception, 2015; 92(3): 190-193.

26. Silva M, Halpern SH. Epidural analgesia for labor: Current techniques. Local Reg Anesth., 2010; 3: 143-153.

27. Silvestre L, Dubois C, Renault M, Rezvani Y, Baulieu EE, Ulmann A, Voluntary interruption of pregnancy with mifepristone (RU 486) and a prostaglandin analogue: a large-scale French experience. $N$ Engl $J$ Med., 1990; 322(10): 645-648.

28. Swahn M, Bygdeman M, The effect of the antiprogestin RU 486 on uterine contractility and sensitivity 


\begin{abstract}
to prostaglandin and oxytocin. Br J Obstet Gynecol.,
\end{abstract} 1988; 95(2): 126-134.

29. Ting W-H, Peng F-H, Lin HH, Lu HF, Hsiao SM, Factors influencing the abortion interval of second trimester pregnancy termination using misoprostol. Taiwan J Obstet Gynecol., 2015; 54(4): 408-411.

30. Urquhart D, Templeton A, Mifepristone (RU 486) and second-trimester termination. Lancet, 1987; 330(8572): 1405.

31. Wong K, Ngai C, Yeo E, Tang L, Ho P, A comparison of two regimens of intravaginal misoprostol for termination of second trimester pregnancy: a randomized comparative trial. Hum Reprod., 2000; 15(3): 709-712.
32. www.anm.ro

33. Yapar EG, Senöz S, Ürkütür M, Batioglu S, Gökmen $\mathrm{O}$, Second trimester pregnancy termination including fetal death: comparison of five different methods. Eur J Obstet Gynecol., 1996; 69(2): 97-102.

34. Zvanca M, Bot M, Radu D, Radu N, Petca A, Impact of early supplementation with low-dose aspirin on functional first trimester parameters in low-risk pregnancies. J Matern Fetal Neonatal Med., 2019; 32(4): 604-609.

35. Zvanca M, Petca A, Bot M, Cell-free fetal DNA in maternal blood - an update of the method and clinical practice. Rev Rom Med Lab., 2014; 22(4): 515-520. 